issn: $1808-799 \mathrm{X}$

ano 5 - número 5 - 2007

documento

\title{
A Economia e a Educação segundo Euvaldo Lodi $\left[{ }^{\star}\right]$
}

José Rodrigues[**]

\section{Introdução}

O período compreendido entre 1930 e 1954 - conhecido como a "Era Vargas" - é, sem dúvida, um período de grande importância para a construção do país em que vivemos hoje. É nesse contexto que a educação nacional, entendida aqui como uma superestrutura, acompanhando as determinações fundamentais da formação social brasileira "começa a ser reconhecida, inclusive no plano institucional, como uma questão nacional", posto que somente no contexto da Era Vargas, o Brasil passa a efetivamente "enfrentar os problemas próprios de uma sociedade burguesa moderna" (Saviani, 1997, p.6). Em outras palavras, as transformações no modo de produção acabam por transformar todo o edifício social, inclusive a educação.

Um organismo privado de hegemonia revela-se particularmente importante, nesse contexto de rápidas transformações, no processo de hegemonia da classe burguesa, em particular para a história das idéias pedagógicas: a Confederação Nacional da Indústria (CNI). Com efeito, na década de 1940 são fundadas duas instituições dirigidas pela CNI que até hoje desempenham um papel relevante na educação da classe trabalhadora: o Serviço Nacional de Aprendizagem Industrial (SENAI), instituído em 1942, e o Serviço Social da Indústria (SESI), de 1946.

Entre 1938 e 1954, a CNI foi presidida por Euvaldo Lodi, figura que toma vulto pela magnitude e organicidade de suas contribuições ao pensamento pedagógico da CNI. Lodi teve seus pronunciamentos organizados, em 1954, pela própria CNI na obra Discursos e 
conferências (Lodi, 1954). Além dessa coletânea, podem ser destacados a conferência Economia e educação (Lodi, 1952a) e o discurso de posse na presidência da CNI (1952b).

Enfim, uma época de grandes transformações sociais, do nascimento de importantes aparelhos privados e públicos de convencimento e coerção, da presença de importantes figuras públicas, dentre elas Euvaldo Lodi[i].

O presente texto tem dois modestos objetivos.

Em primeiro lugar, tornar público a mencionada conferência de Lodi, intitulada Economia $e$ educação - transcrita neste número de TrabalhoNecessário[ii]. A conferência, proferida na então Faculdade Nacional de Filosofia da Universidade do Brasil (atual UFRJ), merece ser mais divulgada posto que pela sua meridiana clareza explicita indubitavelmente as teses da burguesia industrial para a educação da classe trabalhadora brasileira[iii].

Transcrevemos também a biografia de Lodi, elaborada pelo Centro de Pesquisa e Documentação de História Contemporânea do Brasil da Fundação Getúlio Vargas (CPDOC-FGV).

Em segundo lugar, a partir dos pronunciamentos supracitados de Euvaldo Lodi (1952a, 1952b e 1954) procuramos retomar sinteticamente as análises que desenvolvemos em outros textos sobre o pensamento pedagógico industrial, isto é, da Confederação Nacional da Indústria, no período da aventura industrial[iv].

\section{Notas sobre o pensamento pedagógico de Euvaldo Lodi}

\section{Em busca da Nação Industrializada}

O pensamento de Euvaldo Lodi é, sem dúvida, marcado por duas balizas fundamentais. Em primeiro lugar, a luta contra a mentalidade pré-capitalista, isto é, pré-industrial, a qual atribuía ao Brasil sua "natural vocação agrícola". Em segundo lugar, a luta pela superação da chamada improvisação da qualificação profissional, inviável no contexto da indústria moderna. Em síntese, todo pensamento de Euvaldo Lodi é marcado pela luta em defesa do processo de industrialização e pela ideologia do desenvolvimentismo[v].

Nesse sentido, Lodi se contrapõe vigorosamente às visões que defendiam a "circunstancialidade da industrialização brasileira" e a "vocação de país essencialmente agrícola". É de se entender, portanto, porque Lodi se vê empreendendo uma verdadeira aventura:

Nesse quadro, dominado por uma interpretação falsa do papel da indústria, desajudada e incompreendida, o industrial sente-se o protagonista de uma aventura. (Lodi, 1952b, p.9)

Para o dirigente industrial, toda a sociedade - o Estado, os empresários, "o público" estava atravessada pelo preconceito contra as atividades industriais em geral. Para Lodi, esse "preconceito" presente em todo tecido social, condizente com os "interesses 
poderosos", consubstanciou-se numa verdadeira "ideologia da circunstancialidade da indústria" (Idem, ibidem). De uma maneira geral, a sociedade - influenciada por uma "deliberada propaganda" e também "pela educação das elites" - não acreditava na capacidade do industrial brasileiro. Nas palavras de Lodi:

Na comunidade, influenciada pelos hábitos, pelas preferências, pela educação das elites, e por uma deliberada propaganda adversa, encarou-se com suspeição a manufatura nacional. Antes de tudo, pela falta de confiança na capacidade técnica e do trabalho nacional para tarefas reputadas complexas, reclamando qualificações que só a longa formação dos grandes países ocidentais podia possuir. (Lodi, 1952b, p.4-5)

A ideologia da circunstancialidade, portanto, se materializava em cinco aspectos interrelacionados: a não-qualificação do trabalho nacional; a vocação agrícola do país; o trabalho escravo; o alto custo final das mercadorias; e a baixa qualidade das mesmas.

Além de combater a idéia antiindustrialista calcada na suposta vocação agrícola brasileira, Lodi expunha ainda outro suposto sustentáculo dessa ideologia: "a aversão de uma sociedade, por tão longo tempo baseada no labor escravo, ao trabalho material, às habilidades manuais e à técnica" (Lodi, 1952b, p.5). Assim, segundo Lodi, a combinação de um passado escravocrata, sustentáculo da economia primário-exportadora, e as dificuldades técnicas da incipiente produção secundária contribuíram definitivamente para deter a expansão da indústria.

Para Lodi, embora o processo de industrialização tenha se dado pelo estrangulamento externo, ou seja, pelos "azares da conjuntura", o governo não mais poderia ser conivente com a "ideologia da artificialidade da indústria". Defende, assim, a participação ativa do Estado em diversos setores da vida social - "na política comercial, na política monetária, na política fiscal, na organização do mercado de trabalho, na educação e na tecnologia" (Idem, ibidem, p.7) - com vistas à manutenção e diversificação do processo de industrialização.

Enfim, condizente com padrão de acumulação fordista então vigente no capitalismo ocidental, a dirigente da burguesia industrial defende veementemente a construção de um Estado estruturante, capaz de planejar e implementar políticas anticíclicas e pródesenvolvimentistas:

a história econômica recente parece ter demonstrado à farta que a orientação providencial da "mão invisível" não promoveu os reajustamentos automáticos que teriam evitado aos sistemas econômicos o longo e penoso paradeiro dos anos 30. Mais do que nos problemas das flutuações a curto prazo, cumpre uma ação intencional para acelerar o ritmo de crescimento das economias subdesenvolvidas. Na solução dêsses problemas, temos de abandonar o mecanismo inconsciente do "laissez faire" pela técnica racional e consciente do planejamento. (Lodi, 1954, p.136)

O Estado também deveria, na opinião de Lodi, implementar políticas aduaneiras que 
assegurassem um mercado interno estável, com o fito de oferecer "garantia e estímulo aos produtores industriais e agrícolas" e de ampliar a oferta de empregos:

Ingênuos liberais indígenas e porta-vozes conscientes ou inconscientes de grupos de interêsses centralizados no estrangeiro empreenderam ruidosa campanha no Brasil para inocular na opinião pública a idéia de que nossas tarifas devem ser reduzidas. (Lodi, 1954, p.38)

Apesar da feroz crítica às estruturas sociais pré-industriais (o patriarcado rural), não se deve, contudo, depreender a existência de um conflito inconciliável entre as frações rural e a industrial do Capital: é "inteiramente vão, senão nefasto aos interêsses nacionais, supôr que existe algum conflito de interêsses entre a indústria e a agricultura" (Lodi, 1954, p.33). $\mathrm{Na}$ verdade, Lodi procura destacar a complementaridade - inclusive técnica - entre os interesses dessas duas frações burguesas:

A indústria é ainda essencial à agricultura porque cria, prepara a mentalidade técnica e os trabalhadores capazes de desenvolver os processos agrícolas pela mecanização. Como poderemos ter mecanização sem mecânicos? (Lodi, 1954, p.33)

A construção do trinômio desenvolvimento-industrialização-civilização visou operar, dessa forma, a identificação ideológica entre os interesses da burguesia industrial e os interesses de toda a sociedade brasileira:

Desejo e preciso acentuar o fato de não ser a indústria uma classe que pretende impôr predomínio sôbre as outras. [...] Indústria [...] é a utilização da inteligência para multiplicar a eficiência da atividade. Indústria é cooperação social, é a conseqüência dos meios de produção ao alcance do homem e da sua utilização técnica para o bem-estar coletivo. (Lodi, 1954, p.64)

Ou seja, ainda nas palavras de Lodi, "o interesse industrial identifica-se com o interesse geral do país" (Lodi, 1952b, p.13).

\section{Educação para a conciliação de classes}

Num país assumidamente subdesenvolvido, marcado antediluvianamente por gigantesca concentração de renda, a questão do custo do trabalho, isto é, dos salários, precisava ser tratada segundo os interesses da burguesia industrial: aumentar a produção, expandir a produtividade do trabalho e combater as teses "distributivistas". Teses essas que apenas trariam profundas decepções às classes trabalhadoras, podendo causar enormes desastres na economia, caso houvesse uma majoração geral dos salários. "Devemos, portanto, desembaraçarmo-nos de ilusões", afirma o líder, sem margens para dúvida sobre sua posição (Lodi, 1954, p.26).

No panteão das ilusões, causa do baixo padrão de vida do povo brasileiro, Lodi culpa a cultura nacional, desde a carta de Pero Vaz de Caminha: 
Talvez [...] embalado no "berço esplêndido" de falazes riquezas naturais, o Brasil descuidou-se do homem, confiado em extrair ou apanhar na terra as riquezas que o levantariam. (Lodi, 1954:28)

Para Lodi, o Brasil, embora possua alguma variedade de recursos naturais, não dispõe das imensas reservas que outros países possuem. Assim, alerta: é preciso partir do "preparo do homem", seja para um melhor aproveitamento dos recursos disponíveis, seja para a descoberta de novos mananciais naturais. Para argumentar, utiliza-se do exemplo de outros países, que teriam sido bem sucedidos no caminho de investir nos recursos humanos na razão inversa da abundância das riquezas naturais: Japão e Suíça.

Mas, segundo Lodi, os industriais brasileiros, na verdade, já estariam trilhando, mesmo que de forma incipiente, a direção apontada acima. Esteios dessa política de elevação da produtividade, isto é, do "apoio ao trabalhador", seriam o SENAI e o SESI, cujos serviços acrescentam, sem dúvida alguma, o valor dos salários reais dos trabalhadores, proporcionando-lhes, e às suas famílias, vantagens de tôda sorte e de importância inegável para seus níveis de vida. (Lodi, 1954, p.26-7)

Não se resumem à elevação do nível de vida da classe trabalhadora os serviços prestados por essas entidades. Continua Lodi:

Seu maior alcance, entretanto, não é êste, direto, mas o indireto, de alargar a capacidade do homem, já no vigor físico, já nas condições morais e no preparo técnico, para produzir mais e ganhar maiores salários. (Idem, ibidem, p.27)

Assim, segundo Lodi, o caminho para a elevação do nível de vida do trabalhador passa necessariamente por sua capacidade de produzir mais. Essa capacidade, por sua vez, se apóia em dois pilares básicos: preparo educacional-profissional e preparo moral.

A economia, hoje, só pode ser estudada na base da psicologia social. O elemento qualitativo da produção, tanto quanto o quantitativo, muito dependem do estado de espírito do trabalhador. (Lodi, 1954, p.30)

A criação do SESI representou uma estratégia em busca da conciliação das classes, por estar profundamente articulada, no plano internacional, com o nascimento do Estado de Bem-Estar Social. Conciliação (de classes) é, portanto, uma idéia-chave no discurso do industrial:

Todos precisamos uns dos outros e todos devemos ter a consciência de que a vida não se tece de atritos e discórdias, e, sim, de colaboração, para se evitar o desperdício de energias. [...] Os reflexos do problema psicológico e a pressão do fenômeno social são elementos perturbadores da prosperidade geral. (Lodi, 1954:31)

Na constituição do binômio conciliação de classe/produtividade, pode-se, mais uma vez apreender a vocação hegemônica da burguesia industrial, retratada nas palavras de Lodi: "a indústria brasileira se colocou na vanguarda da evolução espiritual. Renovou seu 
espírito para ser digna de sua missão".

\section{Economia e educação}

Também no que tange à educação, o pensamento de Euvaldo Lodi se entrelaça estreitamente com a defesa da inevitabilidade da industrialização brasileira, com a busca da superação da mentalidade antiindustrialista, e com o combate à vocação agrícola e à mentalidade escravocrata do trabalho. Na conferência Economia e educação (Lodi, 1952a), o presidente da CNI busca traçar as mútuas relações entre os dois termos desse binômio, além de indicar os caminhos para que a educação seja indutora do desenvolvimento econômico. Com efeito, Lodi entende que o crescimento econômico implica e pressupõe alterações nas condições sociais e institucionais,

A educação, como técnica, processo, modo sistemático de influir no comportamento humano, transmitindo a experiência acumulada e habilitando a resolver os problemas que a realidade física e social propõe, é uma dessas implicações e um dêsses pressupostos. (Lodi, 1952a, p.4)

A partir desse pressuposto, Lodi desenha rapidamente a evolução da economia brasileira, a qual busca relacionar às funções do sistema educacional. $O$ industrial guia sua análise pela idéia-força da "inadequação funcional entre a educação intencional que se dispensa no país e a realidade material" (Lodi, 1952a, p.5).

Para Lodi, o Brasil percorreu em sua história econômica três etapas distintas, a saber, a fase pré-industrial (1808-1890), dominada pela produção primária, a fase de transição (1890-1939), caracterizada pela expansão da produção para o abastecimento interno, e a fase industrial propriamente dita (a partir de 1939), definida pelo predomínio do mercado interno (Lodi, 1952a, p.6).

Na fase pré-industrial, a "unidade produtora" por excelência é a fazenda. Essa pode ser caracterizada por quatro aspectos fundamentais. Em primeiro lugar, essas unidades produtoras eram de caráter latifundiário; em segundo lugar, baseavam-se, até o fim do século XIX, no trabalho escravo; em terceiro lugar, utilizavam-se de técnicas produtivas extremamente simples; e, por último, poderiam ser consideradas unidades econômicas fechadas, por possuírem subsistência própria. O predomínio da produção primária, cuja consecução era tecnicamente simples e sustentado no trabalho escravo, não produzia qualificações muito variadas (Lodi, 1952a, pp.7 e 8).

Para o presidente da $\mathrm{CNI}$, àquele tipo de estrutura econômica correspondia uma determinada organização social - o patriarcado rural. Organização social que só comportava duas classes sociais: o proprietário rural e o escravo. Para Lodi, a "classe intermediária", composta por alguns profissionais liberais e escassos artífices, era por demais minoritária, caracterizando, portanto, a sociedade patriarcal rural como extremamente "rígida": "Por mais que um escravo suba, jamais se tornará um senhor 
patriarcal; êste, por mais que desça, em posição e fortuna, nunca virá a ser um escravo" (Lodi, 1952a, p.8).

Com relação à fase de transição para a industrialização, Lodi entende que a economia brasileira começou a adquirir lentamente maior complexidade, desenvolvendo algumas atividades secundárias e terciárias. Nessa estrutura econômica, os métodos de produção, embora ainda simples, superavam bastante em complexidade aqueles presentes na fase anterior, já reclamando, assim, maiores qualificações profissionais, alterando profundamente a "paisagem social":

Corresponde a essa estrutura social diferenciada, com várias escalas intermediárias, do ponto de vista da posição social, da posição econômica e da posição política, progressiva mobilidade vertical, que se contrapõe ao quietismo do patriarcado rural e à pequena circulação social de sua fase decadente, o patriarcado urbano. (Lodi, 1952a, p.6)

Por um lado, a nova ordem republicana estabeleceu, para o líder industrial, as bases jurídicas para a ascensão social dos indivíduos, "sem distinção de procedência étnica ou social"; por outro lado, a diversificação e o crescimento da estrutura econômica estabeleceram as bases materiais para a ascensão dos indivíduos ou dos grupos sociais a posições hierárquicas sócio-econômicas mais elevadas (Lodi, 1952a, p.16).

Finalmente, a fase industrial, fruto do processo não-intencional de substituição de importações, se caracteriza pela incipiente superação da etapa das pequenas unidades produtoras, em direção à concentração fabril, à diversificação e à difusão geográfica do parque industrial, inclusive com a implantação da indústria de base. Nessa fase, as unidades fabris já não podem ser erguidas e mantidas pelas poupanças individuais ou familiares, demandando, assim, a constituição de um mercado de capitais, que opere a separação das funções de capitalista e empreendedor (Lodi, 1952a, p.19-20).

A essa complexificação econômica, o líder industrial vincula uma diversificação social, com o nascimento, por exemplo, dos sindicatos de operários - "possibilitando-lhe, assim, acesso à liderança, atribuindo-lhe, assim, função de prestígio social" - e uma diversificação da estrutura do Estado:

As funções públicas adquirem considerável importância e complexidade, exigindo não só um quadro muito ampliado de servidores, como sobretudo, maiores qualificações técnicas e qualidades de comando. (Lodi, 1952a, p.22)

Ao traçar esse panorama evolutivo da economia brasileira, Lodi preparou o terreno para lançar a sua tese educacional básica: a educação nacional foi adequada às estruturas econômicas pré-industrial e transitória, agora (década de 1950) já não mais é.

A educação e a formação profissional, portanto, precisam ser rapidamente modificadas sob pena de obstar irremediavelmente o crescimento econômico-industrial brasileiro.

Lodi explicitamente apóia suas concepções sobre educação nas proposições de Émile 
Durkheim, que por sua vez entende o fenômeno educativo como composto por dois momentos complementares: a educação homogeneizadora e a educação diferenciadora.

No plano específico da educação escolar, para Durkheim, a educação básica deve propiciar aos indivíduos uma educação homogeneizadora de forma a reforçar a "solidariedade mecânica" que derivaria diretamente das semelhanças entre os seres humanos. Esse nível de ensino, portanto, deve

proceder à assimilação do imaturo à comunidade, inculcando-Ihe, independentemente da classe social a que pertence ou da carreira profissional que mais tarde abrace, o mínimo de informações, idéias, interêsses, preferências, hábitos e atitudes essenciais à persistência e à continuidade da cultura social (Lodi, 1952a, p.23)

Com isso, estaria garantida, para Lodi (assim como para Durkheim), a "homogeneidade indispensável à convivência efetiva entre os membros da sociedade". No entanto, o líder industrial, curiosamente, entende a generalização da educação básica a toda sociedade brasileira como uma "utopia nefasta", como será mostrado um pouco mais adiante.

Garantida a homogeneidade entre todos os cidadãos, implementada pela educação básica, restaria ainda para o funcionamento da sociedade um certo grau de diferenciação, promovida pela educação profissional lato sensu, ou seja, pela "educação diferenciadora".

Apoiando-se na exposição das três fases da economia brasileira (pré-industrial, transitória e industrial), Lodi busca relacioná-las à educação, tomando como eixo a idéia-força mencionada mais acima - a "inadequação funcional entre a educação intencional e a realidade material":

Não creio correr o risco de afirmar um paradoxo asseverando que, no sentido vital do terreno, houve mais educação, isto é, formava-se melhor o homem, ao tempo da sociedade patriarcal do que nas fases posteriores. (Lodi, 1952a, p.25)

Para o presidente da CNI, na sociedade pré-industrial brasileira, o complexo cultural indispensável "à persistência da comunidade" era transmitido adequadamente aos imaturos de forma "espontânea", já que as "vivências eram simples":

Comunicava-se a tradição ideológica vigorante, por meio de contatos diretos no ambiente da família, no grupo de jogo, na vizinhança, nas atividades rotineiras de trabalho. (Lodi, 1952a, p. 25-6)

Em outras palavras, na sociedade pré-industrial, as relações sociais acabavam por si mesmas inculcando nos indivíduos a "ideologia vigorante" e os saberes necessários à reprodução dessas mesmas relações sociais. Conseqüentemente, à educação escolar pouca responsabilidade cabia no processo global de hegemonia das classes aristocráticas rurais sobre os demais grupos sociais, ou mesmo na formação profissional dos trabalhadores (ou escravos). Com efeito, para Lodi,

Nêsse período, a educação elementar, ou seja, a aprendizagem da leitura, da escrita e dos 
rudimentos de cálculo, pode-se considerar, não como parte do ensino básico, e sim como instrumento de diferenciação. (Lodi, 1952a, p.26)

A educação básica, o ensino médio e mesmo o ensino superior, no período brasileiro préindustrial, eram apenas distintivos de classe, não passando apenas de "superfetação".

Assim, no período referido, uma educação formal marcada pelo ensino de "humanidades", desprovida de função econômica, aliada à realidade escravocrata acabou por produzir uma "falsa antinomia entre o trabalho físico e o trabalho intelectual". Essas características sócio-econômico-culturais acabaram por se constituir em grandes obstáculos à industrialização, ao desenvolvimento econômico (Lodi, 1952a, p.27-8).

Ou seja, para Lodi a educação no período primário-exportador possui um caráter contraditório. Por um lado, considerando-se a sociedade pré-industrial em si mesma, a educação lhe era plenamente funcional na medida em que contribuía para a cisão cultural entre a classe aristocrática e os demais grupos sociais subalternos. Por outro lado, considerada a sociedade urbano-industrial como télos de um processo civilizatório, a educação teria sido profundamente reacionária, na medida em que contribuiu para estabelecer freios mentais ao "trabalho inteligente", à técnica, à tecnologia, isto é, à própria indústria.

Essas contradições, segundo o então presidente da CNI, agravaram-se durante o período de transição entre a sociedade agrário-rural e a urbano-industrial, conforme a sociedade patriarcal vai se desintegrando, a fazenda latifundiária vai perdendo seu caráter central na organização societária, os grupos sociais fundamentais vão perdendo sua capacidade de "exercer sua ação integrativa ou homogeneizadora" (Lodi, 1952a, p. 28).

A escola, que não colaborara nesse processo hegemônico, não poderia passar a exercê-lo automaticamente. A instituição escolar não estava preparada nem qualitativamente (conteúdo pedagógico) nem quantitativamente para contribuir na manutenção da "solidariedade mecânica", ora em processo de desintegração; tampouco poderia ajudar na construção da nova hegemonia, pois

o espírito de iniciativa, a disciplina, a diligência, a ordem, o "esprit de corps", requeridos numa sociedade que se industrializa, mas dispensáveis numa sociedade patriarcal, baseada no trabalho escravo e em processos de coerção ou compulsão, não foram, no período de transição, inculcados nas gerações submetidas à experiência escolar. (Lodi, 1952a, p.30)

Com relação ao ensino diferenciado, ou seja, o ensino profissional, particularmente o praticado em nível superior, Lodi entende que esse também pouco ajudou ao processo de industrialização, haja vista não ter contribuído para a formação de uma "genuína cultura nacional”, tampouco para a resolução dos problemas práticos. Ou seja, para Lodi, faltou ao ensino diferenciado brasileiro uma verdadeira "orientação pragmática" (Lodi, 1952a, p.33).

Os problemas na relação economia-educação que despontaram na fase de transição só 
poderiam se aprofundar na fase propriamente industrial. Era chegado, assim, o momento histórico de superação do processo de industrialização calcado num movimento nãointencional. Assim, o planejamento estatal do desenvolvimento econômico brasileiro não deveria se restringir às políticas econômicas stricto sensu, mas deveria, sim, abranger a educação:

Temos de preparar o homem para a nova paisagem física e social emergente no Brasil, que não será apenas o resultado de tendências incoercíveis, a soma dos fatos consumados, mas resultante de um propósito racional, a conseqüência de um plano inteligente. Formar homens que o Brasil necessita, eis a tarefa da educação. (Lodi, 1952a, p. 34)

Em síntese, para Lodi, até então, a "industrialização pouco se beneficiou da escolaridade, fazendo-se mesmo independentemente dela", entretanto, isso precisava mudar profundamente.

\section{Formar os homens que o Brasil necessita}

Ainda na conferência Economia e educação, Euvaldo Lodi lança-se na tarefa de propor uma formação humana funcional aos novos tempos da economia brasileira. Para tal, examina o "tríplice aspecto do fenômeno educacional", ou seja, a filosofia, a didática, e a administração, em seu íntimo relacionamento com a economia.

Com relação à administração da educação, Lodi alicerça seu raciocínio no seguinte ponto:

A educação é ao mesmo tempo, um investimento e um consumo; no primeiro sentido, a capacitação dos homens é uma das pedras angulares do desenvolvimento econômico; no segundo, é um dos elementos importantes do bem-estar, indispensável para a fruição plena da vida, e, assim, é o resultado, um fruto do progresso. (Lodi, 1952a, p.34)

Como em um país subdesenvolvido os recursos econômicos são necessariamente reduzidos, é necessário fazer-se uma opção preliminar entre "educação como consumo" e "educação como investimento". Lodi faz sua escolha:

nas condições atuais da economia brasileira, é uma utopia, e utopia nefasta, imaginar que todos possam ter a educação básica necessária. (Lodi, 1952a, p.36. Grifos nossos.)

$\mathrm{Na}$ verdade, em nome do futuro da educação básica da classe trabalhadora, o presidente da CNI condena a universalização da educação básica necessária, do presente, como uma "nefasta utopia".

Operada a transmutação da necessidade em utopia nefasta, Lodi considera imprescindível obter-se a maior rentabilidade possível sobre os recursos aplicados à educação, dadas as condições subdesenvolvidas da nação. Para tal, esboça uma filosofia e uma didática adequadas à premência econômica e à consecução do projeto industrialista:

No ensino básico faz-se preliminàrmente, indispensável uma revisão de sua tábua de 
valores, de sorte a ajustá-la às necessidades de uma sociedade que se industrializa e deve industrializar-se, que se torna cada vez mais urbana. (Lodi, 1952a, p.36. Grifos nossos.)

Ou seja, a filosofia da educação - sua "tábua de valores" - em tempos de industrialização deve pautar o ensino básico no valor da atividade produtiva:

Isto significa elaborar um currículo em que o imaturo adquira a consciência vital da importância da atividade produtiva, isto é, da criação de utilidades, ou seja, do alcance e dignidade do trabalho e qualquer de suas formas, materiais ou espirituais, e assim, dos hábitos, atitudes e preferências que esse valor implica. (Lodi, 1952a, p.37)

Hábitos, atitudes e preferências, aliás, bastante pragmáticas e conectadas ao novo padrão de acumulação:

Relaciona-se com êsse aspecto o objetivo, por demais ponderável para uma economia subdesenvolvida, de modificar racionalmente, através da transformação do educando, os hábitos de consumo, engendrando um comportamento mais compatível com o processo acumulatório imprescindível. (Lodi, 1952a, p.37. Grifos nossos.)

O princípio da produtividade dos recursos aplicados à educação também deveria repercutir nos procedimentos didáticos utilizados nas escolas brasileiras.

Com efeito, a "didática brasileira" não pode se pautar nos mesmos princípios da "didática americana", muito mais dispendiosa, já que voltada ao processo de "individualização".

Como a conferência em questão tem como cenário a Faculdade Nacional de Filosofia, instituição que abrigava o curso de pedagogia, Lodi conclama à "capacidade inventiva de nossos pedagogos" que criem métodos capazes de abranger grupos mais numerosos de discentes.

Para o líder industrial, o "princípio da economicidade" não poderia ficar restrito à educação básica, mas deveria ser estendido também ao ensino diferenciado, fosse de nível médio ou superior. Para Lodi, em qualquer nível escolar caberia "imprimir-Ihe caráter eminentemente utilitário ou pragmático":

Isso não significa dispensar o conteúdo pròpriamente cultural dos currículos profissionais, mas que a primeira preocupação deve ser a de formar um profissional competente, apto, mal egresso das escolas, a contribuir com utilidade e serviços à comunidade. (Lodi, 1952a, p. 38. Grifos nossos.)

A essa preocupação "cultural" dos currículos dos cursos de formação profissionalizante, Lodi articula a capacidade técnica de enfrentar os "genuínos" problemas nacionais. Além disso, ao princípio da economicidade, o líder industrial articula também a preocupação com a flexibilidade:

O princípio que impele a buscar o mais alto rendimento por unidade de capital obriga, num país subdesenvolvido e em expansão, que requer cada dia mais especialização, a orientar 
o ensino vocacional correspondentemente, sem perder de vista que um mínimo de conhecimentos comuns nos setores profissionais é indispensável para assegurar a flexibilidade conveniente a uma economia em que o mercado de trabalho se caracteriza ainda por grande instabilidade. (Lodi, 1952a, p.38-9. Grifos nossos.)

Enfim, Euvaldo Lodi constrói seu pensamento pedagógico buscando articular intimamente economia e educação, seja no momento de formação geral e básica, seja na direção da formação profissional.

A preocupação central do então presidente da CNI é com um plano de industrialização para a sociedade brasileira, plano esse que não só deveria abranger as políticas fiscais, tecnológicas, e industriais propriamente ditas, mas também se espraiaria necessariamente pelo terreno da política educacional.

Portanto, é tarefa da educação preparar o novo homem, habitante e construtor da nova paisagem física e social emergente no Brasil, rompendo definitivamente com a ideologia da artificialidade da indústria.

Essa nova paisagem social, para Lodi, expulsa toda e qualquer possibilidade de improvisação da força de trabalho industrial. As novas técnicas de produção industrial são inacessíveis aos operários sem escolaridade básica (já posta, cabe lembrar, como uma "utopia nefasta") e sem qualificação profissional adequada:

Não me refiro tão só às escolas técnicas, mas à adequada escola primária, que é a base da disciplina social e da habilitação intelectual, sem as quais não há operariado satisfatório. (Lodi, 1954, p.29)

Continuando, Lodi defende veementemente a escolaridade básica como um elemento fundamental para a superação da improvisação e a ampliação da produtividade, como já apontada acima:

Por vêzes pensamos poder resolver os problemas brasileiros do trabalho industrial pela improvisação. As grandes massas trabalhadoras não poderão oferecer índice apreciável de rendimento sem a escolaridade primária, longa e adequada. (Lodi, 1954, p.29)

Logo a seguir, Euvaldo Lodi explicita ainda mais claramente sua compreensão de escola básica. Essa pode ser traduzida como uma escola, com duração de seis a oito horas diárias, na qual o processo educativo deverá assegurar um conjunto de qualidades indispensáveis ao trabalho industrial em grandes unidades fabris: "de cooperação, de disciplina, de pertinácia, de ordem, de asseio, de compreensão".

Para Lodi, se a improvisação na formação dos operários não-qualificados, cerca de $80 \%$ da força de trabalho fabril, traduz-se em grande redução de rendimentos e "danos de toda a espécie", a improvisação da parcela qualificada da força de trabalho é "quase impossível".

A aprendizagem, aí, assenta, em primeiro lugar, em conhecimentos gerais, imprescindíveis 
à compreensão dos processos técnicos e aos cálculos, ainda que elementares, dos aparelhos, dos instrumentos ou dos sistemas de trabalho. (Lodi, 1954, p.30)

A passagem acima afasta a idéia de que, para Lodi, à escola básica cumpre única e exclusivamente a educação atitudinal do trabalhador, apenas ensinando-Ihe a ser ordeiro, obediente, cooperativo e ciente de sua posição no grande concerto sócio-fabril. À escola também cabe fornecer, aos futuros operários, os conhecimentos sobre os quais se assentará a formação profissional propriamente dita:

Não é possível pretender-se a formação de um mecânico ou de um eletricista sem um mínimo de conhecimento de matemática elementar ou de desenho. Tão pouco se habilita o homem a manusear ferramentas, ou a construir peças de máquinas, ou a montá-las, ou a ajustá-las, sem uma lenta e sistemática aprendizagem de operações técnicas. (Lodi, 1954, p.30)

Na medida em que, por um lado, Lodi considera a improvisação formativa do trabalhador incompatível com a "era altamente mecanizada e técnica da produção dos nossos dias", e que, por outro lado, a escola brasileira não fora ainda capaz de fornecer quadros profissionais à altura daquelas demandas, nada mais compreensível do que a solicitação feita ao presidente Getúlio Vargas por uma política integrada.

Para Lodi (1954, p.123), a elevação do nível técnico da indústria brasileira só poderia ser bem sucedida mediante uma política que integrasse o incentivo à imigração de estrangeiros "portadores de conhecimentos e de prática de processos mais avançados de produção"; à importação de equipamentos; à transferência de plantas industriais; à ampliação do ensino técnico-profissional em todos os graus de ensino.

\section{Lodi e a educação da classe trabalhadora}

Marx e Engels[vi] afirmam que as idéias dominantes de uma época nada mais são do que as idéias das classes dominantes, isto é, a expressão das relações (sociais, econômicas, políticas) de sua dominação.

Com efeito, a análise do pensamento de Euvaldo Lodi demonstra que a burguesia industrial, pelo menos desde a década de 1930, vem procurando traçar proposições para a educação da classe trabalhadora em fina sintonia com suas metas econômico-sociais, as quais denominamos télos[vii].

No período aqui analisado, décadas de 1930, 40 e 50, pode-se designar de Nação Industrializada a essa imagem criada pelo pensamento pedagógico da burguesia industrial com o fito de estruturar todas as práticas sociais, em particular a educação[viii]. Como se procurou demonstrar pela breve análise ora apresentada, Lodi empenhou-se em convencer a sociedade política e a sociedade civil de que todos os problemas do Brasil poderiam ser associados ao seu (então recente) passado agrário, isto é, primárioexportador. No discurso teleológico industrial, o Brasil rural, agrário, atrasado, com suas 
“classes parasitárias”, precisaria ser derrotado e, em seu lugar, deveria ser erguida uma Nação Industrializada.

A imagem da nação industrializada congregava, portanto, a superação de todos os problemas brasileiros, do analfabetismo à baixa qualidade dos produtos nacionais, da precária qualificação profissional à criação de um mercado consumidor de massas, da dinamização da ciência à superação do "pauperismo". Ora, a construção de uma nação industrializada impunha necessariamente a participação de todos os segmentos sociais burguesia rural, burguesia comercial, classe trabalhadora, Estado. Desse último, é exigida uma ação planejadora da economia nacional e organizadora de todos os setores da vida social.

A educação, especialmente a formação profissional, também precisaria, na visão burguesa, ser remodelada, já que passou a ser encarada como alavanca para a industrialização. A criação do SENAI e do SESI, de seus congêneres SENAC e SESC[ix], e as chamadas Leis Orgânicas do Ensino[x] demonstram a subordinação da política educacional ao télos Nação Industrializada.

Enfim, a burguesia industrial brasileira, aqui retratada através dos pronunciamentos de Euvaldo Lodi, propugnou que a tarefa da educação seria "formar homens que o Brasil necessita", ou seja, forjar trabalhadores cuja "formação técnica e moral" devesse ser funcionalmente adequada às demandas do capital em sua aventura industrial. Esse horizonte pedagógico - traçado na Era Vargas - continua, em grande medida guiando as proposições da classe dominante para a educação da classe trabalhadora.

\section{REFERÊNCIAS BIBLIOGRÁFICAS}

BIELSCHOWSKY, Ricardo. Pensamento econômico brasileiro: O ciclo ideológico do desenvolvimento. (3ㄹ ed.). Rio de Janeiro: Contraponto, 1996.

FRIGOTTO, Gaudêncio; RODRIGUES, José. Ítalo Bologna. In: FÁVERO, Maria de Lourdes de Albuquerque; BRITTO, Jader de Medeiros. (orgs.). Dicionário de grandes educadores no Brasil. (2 ${ }^{\mathrm{a}}$ ed.). Rio de Janeiro: EdUFRJ/MEC-INEP, 2002.

LODI, Euvaldo. Economia e educação. Rio de Janeiro. 1952a [Conferência pronunciada na Faculdade Nacional de Filosofia, em 15 de maio de 1952.]

Discurso de posse do dr. Euvaldo Lodi na presidência da CNI, pronunciado em 5 de novembro de 1952. Recife: FIEPE, 1952b.

Discursos e conferências. Rio de Janeiro: CNI, 1954.

MARX, Karl. Para a crítica da economia política. São Paulo: Abril Cultural, 1982.

MARX, Karl; ENGELS, Friedrich. A ideologia alemã. (6ª ed.). São Paulo: Hucitec, 1987.

RODRIGUES, José. O moderno príncipe industrial: o pensamento pedagógico da Confederação Nacional da Indústria. Campinas: Autores Associados, 1998.

. Celso Suckow da Fonseca e a sua "História do ensino industrial no Brasil".

Revista Brasileira de História da Educação. Campinas: SBHE, v.2, n 4, pp.47-74, 2002.

A nova educação superior brasileira no padrão de acumulação flexível. 
QUARTIERO, Elisa Maria; BIANCHETTI, Lucídio. Educação corporativa: mundo do trabalho e do conhecimento: aproximações. Santa Cruz do Sul: EDUNISC; São Paulo: Cortez, 2005b.

Frações burguesas em disputa e a educação superior. Revista Brasileira de Educação. Rio de Janeiro: Anped; Campinas: Autores Associados, v.12, n.34, pp.120-136, 2007

SAVIANI, Dermeval. A nova lei da educação: trajetória, limites e perspectivas. Campinas: Autores Associados, 1997.

* Ver o discurso de Euvaldo Lodi em documentos e a sua biografia.

** Professor da Faculdade de Educação da Universidade Federal Fluminense, membro do Núcleo de Estudos, Documentação e Dados sobre Trabalho e Educação. Doutor em Educação pela Universidade Estadual de Campinas (1997). Pesquisador do CNPq, atualmente em estágio de pós-doutoramento em Ciência Política (Unicamp).

[i] Convidamos o leitor a compulsar nossas contribuições sobre o pensamento pedagógico de Celso Suckow da Fonseca (Rodrigues, 2002) e de Ítalo Bologna (Frigotto, Rodrigues, 2002).

[ii] Agradecemos a Yuri Peres pelo cuidadoso trabalho de fiel transcrição do documento original.

[iii] Como o leitor poderá verificar que, se por um lado as teses em si vêm sendo alteradas, por outro lado, a lógica que informa o pensamento da burguesia industrial não sofreu solução de continuidade.

[iv] Cf. principalmente Rodrigues (1998).

[v] O desenvolvimentismo pode ser sintetizado através de quatro características: (a) a industrialização é a via de superação da pobreza; (b) não há meios de alcançar uma industrialização eficiente através das forças espontâneas de mercado; por isso, é necessário que o Estado planeje a economia; (c) o planejamento deve definir a expansão dos setores econômicos, além dos instrumentos da mesma; e (d) o Estado deve ordenar também a execução da expansão, captando e orientando recursos financeiros, e promovendo investimentos diretos naqueles setores em que a iniciativa privada seja insuficiente (Bielschowsky, 1996, p.7).

[vi] Cf. Marx (1982) e Marx; Engels (1987).

[vii] Télos é, portanto, uma imagem construída pelo discurso burguês com o propósito de subsumir os interesses do conjunto da sociedade, em particular, da classe trabalhadora, aos interesses particulares da classe dominante, no caso, da fração industrial da burguesia.

[viii] Com efeito, ao longo de suas quase sete décadas de existência, a CNI produziu mais dois outros télos, além do Nação Industrializada: País Desenvolvido e Economia Competitiva. Para os dois télos, ver Rodrigues (1998). Sobre a educação superior sob o télos Economia competitiva, ver Rodrigues (2005a, 2007).

[ix] Respectivamente, Serviço Nacional de Aprendizagem Comercial e Serviço Social da Indústria.

[x] Conjunto de decretos-leis editados a partir de 1942, quando da gestão de Gustavo Capanema no MEC.

volta 


\section{DOCUMENTO}

\section{Economia e educação}

EUVALDO LODI

CONFERÊNCIA pronunciada na Faculdade Nacional de Filosofia, Universidade do Brasil, em 15 de maio de 1952*.

file://C:LDocuments and Settings\AdministradorlMeus documentoslMinhas WebsINED... 11/9/2008 
Considero alta distinção e auspiciosa oportunidade ocupar a tribuna que fidalgamente me ofereceis. Daqui, desta colmeia de cultura, abrangemos com o pensamento as perspectivas de nosso futuro espiritual, certos, como devemos estar, de que as conquistas do progresso e da civilização, por mais admiráveis, não bastam para assinalar na História o destino das grandes nações: é mister, ainda, que, para sobreviverem, acresçam aos esplendores da evolução material traços profundos da cultura do espírito, recolhendo, fecundando e perpetuando os tesouros da ciência, da filosofia e das artes.

Bem feliz seria eu se, correspondendo à gentileza de vosso apêlo, pudesse contribuir, não direi para enriquecer, mas para avivar os aspectos do palpitante problema, visceral para nós, das relações da economia com a educação,- problema que se multiplica em outros, todos de grande premência no que diz respeito à definição e estabilização de nosso caráter de nação civilizada e cristã.

O problema fundamental da política econômica dêste país, como de grande parte das áreas do mundo, é o de lhe acelerar o desenvolvimento econômico, elevando os padrões gerais da vida. A intensificação do ritmo de crescimento material implica, porém, de um lado, em alterações nas condições sociais e institucionais e, de outro, as pressupõe. A educação, como técnica, processo, modo sistemático de influir no comportamento humano, transmitindo a experiência acumulada e habilitando a resolver os problemas que a realidade física e social propõe, é uma dessas implicações e um dêsses pressupostos. Requer a expansão econômica do país, não só mais educação, no sentido quantitativo, como adaptações nos seus objetivos e nos seus meios, isto é, na natureza e na qualidade da educação ministrada. A elevação da renda nacional, que é a expressão global do progresso econômico, se permite dedicar mais recursos ao processo educativo, resulta, também, em transformações sociais que, por sua vez, reclamam educação que integre os indivíduos na cambiante vida social, proporcionando-lhes, à medida que os prepara para exercerem função efetiva na sociedade de que participam, condições para a formação equilibrada de sua personalidade.

No Brasil, sem nenhuma intenção delibera-

da, ocorreu, e está ocorrendo, a intensificação e diversificação da atividade 
econômica. Todavia, assim como acontece com outras instituições sociais, a educação sistemática, de modo geral, antes de concorrer para imprimir maior rapidez àquele processo e para promover os ajustamentos entre o indivíduo e as novas condições sociais emergentes, parece, mais por omissão do que por participação, ter nêle papel negativo ou positivamente despiciendo. Afigura-se, com efeito, haver, dêste ponto de vista, notória inadequação funcional entre a educação intencional que se dispensa no país e a realidade material e social.

Descrevamos e analisemos, brevemente, nos aspectos essenciais, 0 processo de crescimento da economia nacional, indicando suas principais tendências atuais, com seus efeitos mais flagrantes sôbre a estrutura social. Em segundo lugar, tentemos demonstrar que a educação nacional não se tem coadunado com aquele crescimento, contribuindo para orientá-lo e intensifica-lo, e examinemos as razões mais ponderáveis desse divórcio.

\section{I - TRAÇOS DA EVOLUÇÃO ECONÔMICA E SOCIAL DO BRASIL}

Podemos distinguir, em rápida apreciação do processo de crescimento da economia nacional,

nos últimos 150 anos, três fases típicas, definidas idealmente por características econômicas e sociais peculiares. São elas, do ponto de vista das condições objetivas, a fase pré-industrial (1808-1890), dominada pela produção primária de exportação; a fase de transição (1890-1939), de expansão da produção para abastecimento do país, e a fase industrial propriamente dita (1939), de predomínio do mercado interno.

\section{A FASE PRÉ-INDUSTRIAL}

Com a liberdade do comércio, decorrente da abertura dos portos, e com a independência política não superamos simultaneamente o "status" de uma sociedade colonial. As flutuações da atividade econômica dependiam integralmente do comportamento dos mercados externos - e a superestrutura comercial e financeira se assinalava pela predominância dos capitais e firmas estrangeiras. Dest'arte, continuou débil ou praticamente nulo, malgrado a 
soberania política, o poder de contrôle interno da economia nacional.

A economia do país assentava na exploração de dois ou três produtos de exportação, matérias primas ou artigos de alimentação. Constituía-se de alguns centros produtores independentes entre

si, formando, como já denominou, verdadeiro arquipélago econômico, voltados não para a satisfação das necessidades internas, mas para o suprimento do mercado internacional. Na realidade, não havia propriamente um sistema econômico nacional coincidente com a área política do país, grande parte da qual não se subordinava aos estímulos, motivações e mecanismos da economia monetária.

As unidades produtoras eram as fazendas, que apresentavam quatro características essenciais. Em primeiro lugar, eram propriedades latifundiárias; em segundo,baseavam -se, até quase o fim do século, no trabalho escravo; em terceiro, reclamavam uma técnica produtora simples, apoiada na exploração extensiva, em regra predatória da terra e, finalmente, do ponto de vista das relações internas de trocas, podiam considerar-se economias "fechadas", com subsistência própria.

A população, muito pequena para a vastidão do território, era dispersa. Na penúltima década do período considerado, a área de maior concentração demográfica já era esta cidade do Rio de Janeiro, com pouco mais 250.000 habitantes, correspondentes a $2,7 \%$ da população total. Com efeito, as cidades, centros administrativos, loca-

lizadas, via de regra, na orla marítima, viviam em tôrno do pôrto, isto é, direta ou indiretamente ocupadas nas operações de importação e exportação.

A êsse tipo de estrutura econômica respondia determina organização social, cujo esquema se pode fácilmente descrever. Em tal ordem social, definida pelo patriarcado rural, há via duas classes distintas, réplica das condições de produção dominantes: o proprietário rural e o escravo, com funções econômicas e sociais prefixadas. Mas existia uma indefinida classe intermediária, formada de funcionários, homens das profissões liberais, aquêles dedicados aos serviços ligados ao comércio externo, e escassos artífices, agregados ou clientes, imigrantes ou escravos libertos.

A estrutura social caracteriza-se pela rigidez. Por mais que um escravo 
suba jamais se tornará um senhor patriarcal; êste, por mais que desça, em posição e fortuna, nunca virá a ser escravo os elementos dinâmicos dessa sociedade, marginais às pilantras básicas, não dispõem ainda de fôrça bastante para alterar-Ihe a composição. Nesse sistema, fundado na produção primária e no trabalho escravo, não eram necessárias técnicas nem qualificações muito variadas.

\section{A FASE DA TRANSIÇÃO}

A organização econômica e social, cujo tipo ideal apenas esboçámos, não pôde resistir à influência transformadora de fatores internos e externos. Com efeito, é impossível, em primeiro lugar, desconhecer os efeitos que nela teria a proibição do tráfico africano. Antes de tudo, traduziu-se em "liberar capitais consideráveis" aplicados na importação do escravo. "Os capitais que eram empregados nessas ilícitas transações - salienta um relatório oficial da época - afluíram à praça de que resultou uma baixa considerável nos descontos; o dinheiro abundava e uma subida extraordinária teve lugar nos preços das ações de quasi todas as companhias”. Depois, a proibição, encarecendo a mãode-obra servil, obrigou a considerar, sèriamente, as possibilidades do trabalho livre assalariado, que, daí por diante, vai, gradativamente, ganhando terreno. Segundo um cálculo, no último ano do regime escravocrata, apenas $5 \%$ da população total eram escravos.

Em segundo lugar, nossa capacidade de exportar, a que se arrimava a ordem econômica pré-industrial, não pôde acompanhar o crescimento das necessidades de consumo interno, ampliando não só pelo aumento rápido da população como pela contínua elevação dos níveis culturais e pó-

líticos. Enquanto os países industriais experimentam ritmo acelerado de suas rendas, eleva-se, paralelamente, salvo as crises episódicas da exportação, a procura internacional dos produtos coloniais, que, assim, assegurariam, por largo tempo, mesmo diante do crescimento demográfico, relativa prosperidade e, consequentemente, a estabilidade das instituições sociais e políticas. No último quarto, porém, do século passado e, sobretudo, nas primeiras décadas do corrente, declina o ritmo de expansão industrial dos países europeus, a 
principal fonte propulsora do desenvolvimento das economias coloniais. Coincide a queda relativa na procura internacional de produtos primários com o alargamento de sua oferta, à medida que novas áreas coloniais se incorporam à economia mundial e aumenta, relativamente, a capacidade dos produtores tradicionais. A consequência final é a deterioração das relações de intercâmbio, ou seja, a diminuição da capacidade de compra externa, a queda " per capita" das importações, com a redução do montante de bens disponíveis para o consumo interno. Fenômeno importante, embora derivado, é a crescente dificuldade de absorção eficiente da mão-de-obra pelo sistema de produção colonial, especialmente após a abolição da escravatura.

A contradição entra a incapacidade do siste-

ma econômico colonial e as crescentes necessidades do país engendrou novas modalidades alternativas da aplicação dos recursos, constituindo-se em duplo processo: de um lado, na substituição de importações, mediante a progressiva implantação de atividades competitivas internas e de outro, na diversificação das exportações.

No que concerne ao último aspecto, que só mais tarde, por ocasião dos anos críticos do penúltimo decênio, assumiu proporções mais significativas, ocorreu, lenta e descontinuamente, o desdobramento dos artigos de exportação, que tem como causas imediatas as flutuações na procura internacional, a emergência de uma nova demanda e, como condição, a possibilidade de emprêgo remunerado, em setores marginais, dos fatores sub-utilizados na produção principal. Resultaram dessa evolução, no plano interno, a tendência à policultura e a exploração sistemática, com vistas á exportação, de certos recursos naturais inexplorados, minerais e vegetais. No plano externo, conquanto em gráu ainda relativamente reduzido, atenua-se a vulnerabilidade da economia às variações da conjuntura externa e alcança-se posição mais independente, no todo, em relação ao contrôle hegemônico de certos mercados.

A substituição de importações começa pela

produção de artigos grosseiros e os setores inicialmente mais importantes são as manufaturas têxteis de algodão, a fabricação de alimentos, de vestuário e outras mercadorias de consumo doméstico. A 1.a Guerra Mundial, contraindo o suprimento proveniente do estrangeiro, acelerou êsse processo, incorporou 
novos tipos de atividade ao parque febril nacional. No último ano da monarquia, o valor da produção industrial mal atingia 500 milhões de cruzeiros. Resultante dessa incipiente industrialização, registrava-se, já em 1920, uma produção manufatureira avaliada em 3 bilhões de cruzeiros. Tais resultados confirmam-se não só na elevação do número de unidades fabrís, como no de operários; assim, em 1889, existiam, no país, cerca de 650 estabelecimentos industriais, com 54.000 operários e, em 1920, 13.000 estabelecimentos, com 300.000 trabalhadores. No decênio que abrange a 1. ${ }^{\text {a }}$ Guerra Mundial triplicou o volume de bens produzidos pela indústria. A crise dos anos 30 agravou as causas dessa transformação na fisionomia econômica do país. Entre as duas Grandes Guerras, significativo se mostrou o impulso da industrialização. Em 1939, contentavam-se cêrca de 50.000 estabelecimentos fabrís, ocupando aproximadamente 1.000 .000 de operários, com uma produção de 17,5 bilhões de cruzeiros. Em comparação com os dados mencio-

nados do último ano da monarquia, o volume de bens produzidos pela indústria, e que, de outra fórma, teriam de ser importados e, assim em face da rígida limitação da capacidade de importar, resultariam em necessidades insatisfeitas, aumentou dezessete vezes.

O crescimento da indústria nacional, que se teria de localizar, por sua natureza, nos centros urbanos, e o consequente aumento dos serviços, induziram a uma acelerada expansão das cidades. De outra parte, a produção manufatureira, como se destina ao mercado interno e por si mesma cria uma procura de matérias primas, constitui fator de unificação dos mercados regionais e tornou-se, ao mesmo tempo, uma das principais beneficiárias dêsse resultado. O crescente consumo das cidades determinou, por sua vez, progressiva demanda de produtos agrícolas e pecuários que antes representavam, nêste país, relegada atividade subsidiária.

Veremos, em resumo, na fase de transição em que a economia do país, de estrutura de produção colonial, naturalmente singela, adquire os caracteres de estrutura econômica mais complexa, com a maior participação das atividades secundárias e terciárias na renda nacional, os aspectos mais importantes. Em primeiro lugar, deu-se a implantação de indústrias leves de bens de consu-

mo, em geral de pequeno porte, requerendo capitais relativamente modestos, que se podem formar por indivíduos ou por famílias isoladamente, sem apêlo efetivo à participação de estranhos, e supondo métodos e técnicas de produção 
que, sendo bem mais complexos que os prevalecentes, reclamam maiores qualificações e especializações. Em segundo lugar, substitui-se, na emprêsa, o trabalho escravo pelo trabalho livre, assalariado, conquanto os sistemas de remuneração, adotados nas fábricas e nas fazendas, fossem diferentes. Em terceiro lugar, expandiu-se o comércio interno, o que quer dizer que a economia se tornou mais monetária, requerendo quantidade correspondentemente maior de meios de pagamentos. Em quarto lugar, ocorreu a multiplicação das unidades produtoras, quer pelo número de empresas industriais e comerciais estabelecidas, quer pelo desenvolvimento da pequena propriedade agrária, destinada à agricultura de abastecimento. Decorre daí o aumento da competição, que exige comportamento econômico baseado no cálculo dos custos e na previsão dos lucros, em suma, na organização racional da produção. Noutras palavras, tornam-se as firmas mais capitalísticas. Finalmente, em consequência de todas essas transformações e ao mesmo tempo, facilitando-as, crescem os núcleos urbanos.

À medida que a iniciativa e as inversões internas ganham importância, em relação ao comércio exterior, como fator dinâmico do desenvolvimento econômico, ocorre uma mudança na estrutura social do país, que se em parte se originou naquele processo, derivou, também, de outras causas e, simultaneamente, propiciou condições para se prosseguimento.

Alterou-se profundamente, nêsse período, a paisagem social. A abolição da escravatura incluiu, ao menos formalmente, no mercado livre de trabalho os recém-libertos, que, gradativamente, passaram a constituir parcela considerável do proletariado urbano e rural, já iniciado com a proibição do tráfico africano, e de crescente significação. A abolição promove a imigração, engendrando problemas de contato entre culturas. Com o desenvolvimento da pequena e média indústria e a decorrente expansão dos serviços, foi-se criando uma diversificada classe média que contribuiria, nas últimas etapas desse período, com elementos e expoentes da direção econômica e administrativa do país. Contemporaneamente, no campo, ao lado dos grandes proprietários, preocupados com a agricultura de exportação, surgiram os pequenos fazendeiros, voltados para a produção destinada ao abastecimento interno.

Corresponde a essa estrutura social diferenciada com várias escaladas 
intermediárias, do ponto de vista da posição social, da posição econômica e da posição política, progressiva mobilidade vertical, que se contrapõe ao quietismo do patriarcado rural e à pequena circulação social de sua fase decadente, o patriarcado urbano. A constituição republicana, na sua declaração de direitos, oferece a base jurídica para a ascensão individual sem distinção de procedência étnica ou social, mas o processo de diversificação da estrutura econômica e seu crescimento proporcionaram as bases materiais, que tornaram possíveis o acesso de classes ou grupos colocados em posição inferior na hierarquia social econômica, a classes ou grupos, mais elevados. A progressiva integração dos mercados num mercado nacional e a expansão dos núcleos urbanos alteiam a importância dos contatos sociais indiretos, o que significa adquirirem maior importância os grupos derivados, enquanto a família e a vizinhança deixam de ter a dominante influência anterior. Cada indivíduo, ao contrário do que ocorria na sociedade patriarcal rural, pertence a vários grupos, cada um dos quais exerce nele atuação diversa.

\section{A FASE INDUSTRIAL}

O processo de substituição de importações vigorante, sem nenhuma intenção deliberada e sem a continuidade desejável, na fase de transi-

ção, processo, cujo mecanismo e cujos efeitos principais delineei sumàriamente, prossegue na economia brasileira.

Com efeito, por um lado, as mesmas condições que deram origem à industrialização do país, reclamaram a produção interna de bens de capital com a análoga finalidade de tornar menos dependentes das vicissitudes de nosso poder aquisitivo externo os suprimentos de materiais indispensáveis às atividades econômicas internas. Em suma, a capacidade de compra do país no exterior não se equilibrou com as necessidades nossas de produtos estrangeiros. Se, todavia, êsse desajustamento persiste, acontece, ao mesmo passo, que melhora a produtividade, se amplia o mercado interno e se elevam os padrões de vida.

$\mathrm{Na}$ realidade, durante a última guerra, foi surpreendente o crescimento industrial. Em 1949, contavam-se no país aproximadamente 90.000 
estabelecimentos industriais, ocupando 1.500 .000 operários; em têrmos reais, o volume de bens produzidos pela indústria aumentou de cêrca de duas vezes em relação a 1939. Como já disse, enquanto cada brasileiro, ao tempo da proclamação da República, considerando o mesmo poder aquisitivo da moeda, dispunha de $\mathrm{Cr} \$ 30,00$ de produtos industriais de fabricação nacional, em 1949, tinha a sua disposição $\mathrm{Cr} \$ 267,00$, ou seja nove vezes

mais. Naquela data, os bens disponíveis "per capita" equivaliam a $\operatorname{Cr} \$ 180,00$ e na última correspondiam a $\mathrm{Cr} \$ 560,00$, isto é um aumento de 3 vezes. $\mathrm{Na}$ agricultura, posto que em escala menor e manifestando-se, sobretudo, em certas áreas, precisamente as mais próximas dos centros industriais, deu-se uma réplica desse processo de expansão. Aquela se está tornando, também, ao menos nessas zonas, mais capitalística, o que exprime que, para o mesmo volume de produção, tende a empregar mais máquinas do que mão-de-obra. Basta referir a êsse respeito que dados recentíssimos revelam, atualmente, no país, a existência de cêrca de 19.000 tratores.

Por outro lado, a intensidade do desenvolvimento e, por conseguinte, a elevação dos níveis de consumo teria maior expressão caso tivesse havido aplicação racional das dívidas entre os tipos de importação e distribuição mais adequada das inversões, as quais se tornaram, como se viu, o fator dinâmico mais importante da atividade econômica do país. De fato, é preciso dizê-lo com toda a coragem, a expansão da produção nacional enfrenta atualmente 0 obstáculo, felizmente superável, dos custos crescentes. Decorre essa anomalia da desproporção existente entre o crescimento dos setores basicos, cuja característica é a criação de "economias externas", isto é, de dis-

ponibilidades que propiciam o desenvolvimento geral, e os demais setores produtivos. Essa desarmonia resultou, em parte, do volume de economias disponíveis e também do vulto e tipos de importações, que, em regra, exige a produção básica, mas terá sua causa principal em uma política econômica racionalmente orientada. Tal política não significa o abandono da livre iniciativa, mas, ao contrário, a criação de condições que lhe permitem cumprir satisfatòriamente, na sua órbita própria, as tarefas que Ihe são cometidas. A coordenação da livre emprêsa e do empreendimento público, para o objetivo de intensificar o rítmo do desenvolvimento econômico, impõe uma política de investimentos e de preparação sistemática do homem, que pressupõe o 
planejamento - vale dizer, a liberação, de maneira equilibrada, de sorte a possibilitar sua plena expansão - das tendências fundamentais que vêm impulsionando històricamente a economia brasileira.

Há, sem embargo três traços característicos na fase contemporânea. Primeiramente, atividade industrial inicia a superação da etapa das pequenas unidades produtoras e caminha no sentido da concentração fabril. Agora, já não bastam as economias individuais ou da família; é mister recorrer, para a obtenção dos meios necessários, ao mercado de capitais, para onde encaminham suas

poupanças os que conseguem consumir menos do que a totalidade de seus rendimentos. Daí defluem três consequências importantes. Antes de tudo, a necessidade de instituição de mecanismos através dos quais se congreguem e se distribuam essas sobras; depois, efeito relevante, a substituição da sociedade anônima da família por uma verdadeira sociedade anônima, ou seja, uma corporação autêntica, de que são proprietários milhares de pessoas de diferentes condições econômicas e sociais; finalmente, distinguindo-se dos proprietários, o gerente ou empresário, que terá às vezes, pequena parte do capital, começa a adquirir crescente importância a figura do administrador. Simultâneamente, no plano geográfico, ocorre uma difusão da produção manufatureira, que penetra o interior e altera a configuração econômica de áreas antes dominadas apenas pela produção agro-pastoril. Em segundo lugar, graças à ampliação do mercado, tende a incrementar-se a especialização fabril. Em terceiro lugar, fato de extrema relevância, surge a indústria pesada e implanta-se a produção básica mais complexa. As indústrias químicas, as mecânicas, as de fertilizantes, as de matérias elétricos e as de implementos agrícolas constituem novos rumos para os quais se volta generalizada atenção.

A intensificação da produção secundária,

manufatureira, e dos serviços correspondentes, públicos ou privados, sua extensão pelo interior do país e em parte a incipiente mas intensa mecanização da agricultura, resultaram na aceleração do processo de concentração urbana, não se limitando, desta feita, às cidades litorâneas ou aos antigos municípios das capitais. De fato, enquanto se verifica, entre os dois Censos (1940 e 1950), 
um aumento na população total do país de cêrca de $28 \%$, o número de cidades de mais de 10.000 habitantes cresceu de 147 para 489, com um aumento de sua população urbana, em média, de $63 \%$. As capitais, por sua vez, tiveram as populações aumentadas em $48 \%$. Não é o momento de volver a examinar a velha e debatida questão de êsse crescimento, nas proporções em que se operou, foi ou não benéfico à agricultura; cumpre, apenas, certificá-lo para apontar as exigências de serviços públicos, e, pois, de educação que êsse surgimento de novas cidades e o agigantamento de cidades já existentes representam.

Acentuam-se, nesta fase, as tendências sociais que apontaram no período de transição.

Três aspectos, no entanto, sobrelevam na fase em que estamos vivendo. Em primeiro lugar, salienta-se a organização dos trabalhadores em entidades sindicais, que se constituem em grupos sociais de influência marcante na formação pó-

lítica e social do obreiro, possibilitando-Ihe o acesso à liderança, atribuindo-Ihe, assim, função mediante a qual conquista uma posição de prestígio social. Além disto, o sindicato é uma manifestação de solidariedade orgânica ou inteligente e representa, pois, uma superação dos processos puramente competitivos e individuais. Significa isto que o operário passa a encarar seus interêsses próprios, na perspectiva do interêsse comum.

Depois, a implantação das indústrias pesadas e a concentração das indústrias leves impõem cada vez mais, no plano da iniciativa capitalística, uma mudança do ângulo, que leva a considerar, interrelacionadamente, os interêsses e os problemas econômicos e sociais das emprêsas e dos grupos de emprêsas.

Finalmente, o aparecimento de grandes corporações e o desenvolvimento dos serviços públicos, reclamando a criação de numerosos órgãos gerais e específicos, promoveram o crescimento da burocracia, isto é, de estrutura e mecanismos adequados ao exercício da autoridade, ao exame dos problemas, ao encaminhamento das soluções. As funções públicas adquirem considerável importância e complexidade, exigindo não só um quadro muito ampliado de servidores, como, sobretudo, maiores qualificações técnicas e qualidades de comando. 


\section{II - A FUNÇÃO EDUCATIVA NAS TRÊS FASES}

Os estudiosos do fenômeno educacional, como fato social, costumam distinguir dois momentos no processo educativo. O primeiro, cujo equivalente no sistema escolar atual seria a educação básica ou comum, destina-se a proceder à assimilação do imaturo à comunidade, inculcando-lhe, independentemente da classe social a qual pertença ou da carreira que mais tarde abrace, o mínimo de informações, idéias, interêsses, preferências, hábitos e atitudes essenciais à persistência e à continuidade da cultura social de seu grupo; assegura-se, assim, a homogeneidade indispensável à convivência efetiva entre os membros da sociedade. O segundo, que corresponde, nos sistemas escolares atuais, ao ensino diferenciado, seja qual fôr sua modalidade ou nível, visa a preparar, de uma parte, o indivíduo para participar de sua casta, estamento ou classe, e, de outra, para ingressar num meio profissional definido. Como disse Durkheim, a sociedade não pode sobreviver, se entre seus membros não existe suficiente homogeneidade: a educação perpetua e reforça essa homogeneidade, fixando, de antemão, na alma do jovem as semelhanças essenciais que exige a vida coletiva. De outro turno, porém, toda cooperação, sem certa diversidade,

seria impossível: a educação assegura a persistência dessa diversidade necessária, diversificando-se e especializando ela própria.

Em qualquer sociedade, salvo nas pré-históricas, que "não representam mais que um momento lógico na história da humanidade", deparam-se essas duas fases. Não obstante, à medida que se torna mais complexa a sociedade, em virtude da divisão social do trabalho, mais longa e discriminada se apresenta a fase de diferenciação.

Pressupondo um mínimo de atividade diferenciada, quanto mais primitiva é a sociedade, mais a educação, em qualquer de seus momentos, se confunde com a própria vida. Inversamente, á proporção que a estrutura social se complica, a educação, soma apreciável dos meios de formar as novas gerações, transmitindo-lhes, reelaborando-o, o legado da experiência, adquire caráter próprio, segrega-se e passa a exigir ambiente especial e métodos intencionais peculiares. Tal evolução, como sabeis, é inelutável, mas tende a compartir a educação, dissociando-a, separando-a, distanciando-a da vida, para 
qual, na verdade, Ihe incumbe preparar os educandos. Assim, a escola, que é êsse ambiente necessário, mas artificial, da formação deliberada do imaturo, corre o risco de se desvincular da sociedade, inepta para modificá-la, incapaz de acompanhar

suas transformações ou de obstar aos efeitos perturbadores que, sôbre a individualidade do educando, exerçam outros meios, às vezes poderosos, de modelação anímica.

No Brasil, a educação, na fase de transição antes descrita, não acompanhou, como lhe caberia, as transformações econômicas e sociais e, pois, muitos menos, contribuiu construtivamente para orientá-las, segundo suas tendências naturais. Com efeito, não é possível negar, por mais que o desejemos, pois aí estão os fatos e nos autorizam essa interpretação os luminosos estudos de conceituados mestres desta Faculdade e de sua congênere de São Paulo, que a educação tem sido, desde então, quantitativamente deficiente e qualitativamente inadequada.

Não creio correr o risco de afirmar um paradoxo asseverando que, no sentido vital do termo, houve mais educação, isto é, formava-se melhor o homem, ao tempo da sociedade patriarcal do que nas fases posteriores.

$\mathrm{Na}$ sociedade agrária, pré-industrial, transmitia-se diretamente 0 complexo cultural indispensável à persistência da comunidade. A educação era, antes que sistemática, sobretudo espontânea. As vivências necessárias à participação integral na comunidade eram simples. Comunicava-se a tradição ideológica vigorante, por

meio de contatos diretos no ambiente da família, no grupo do jogo, na vizinhança, nas atividades rotineiras de trabalho. Adquira assim o indivíduo vivendo ou fazendo, as semelhanças que o tornavam membro da sociedade. Não era imperiosa à manutenção da coesão social, em vista da influência dominante dos grupos primários, da simplicidade das relações humanas, do quietismo social, observar processos sistemáticos de aprendizagem. Dest'arte, no plano da homogeneização, entendida no sentido "durkheimniano" e não no de uma uniformização dos indivíduos a educação espontânea era suficiente tanto do ponto de vista da quantidade quanto da qualidade.

Nêsse período, a educação elementar, ou seja a aprendizagem da leitura, da escrita e dos rudimentos de cálculo, pode-se considerar, não como parte do ensino básico, e, sim, como instrumento de diferenciação. A massa, se assim se 
pode denominar a grande parte da população sem posses ou sem terras, não carece, ainda, dessas técnicas da absorção da cultura. Saber lêr e escrever distingue, pois, socialmente. Outro fator diferenciador, no sentido de preparar para participação numa classe, era o ensino de humanidades, ministrado, na fase que estamos considerando, em alguns colégios de padres, ou sob forma fragmentária em "aulas" avulsas ou nos cur-

sos anexos propedêuticos às escolas superiores. De fato, como assinala Milton Rodrigues, desde meados do século XVIII desaparecera no país o ensino básico. A educação profissional desnecessária para a maioria, ministrava-se nas escolas estabelecidas desde D. João VI, "verdadeiras escolas técnicas de gráu superior", onde se adquiram habilidades e não cultura. Mesmo, porém, essas habilidades resultavam, não raro, de tecnologias elaboradas noutros países, em meio físico e social diferente e, portanto, sem correlação com os problemas propostos por uma realidade física e social diversa. Em suma, o ensino médio, enquanto se pode dizer que existisse, e o ensino superior, na medida em que não era apenas profissional, constituiam marca de distinção e de prestígio, um consumo conspícuo; não introduzia uma cultura, mas proporcionava os elementos de uma "cultura de importação". Neste sentido, não passava de uma superfetação, cujos efeitos imediatos não seriam graves, mas teriam repercussões duradouras. Resultariam falsa antinomia entre o trabalho físico e o trabalho intelectual, antinomia cujas raízes se encontram na estrutura social, definida para senhores e escravos e cujos efeitos perduram e, mau grado a influência transformadora das correntes imigratórias, constituem ainda obstáculo à efi-

ciência e, pois à industrialização, ou seja, ao desenvolvimento econômico.

As insuficiências quantitativas e qualitativas da educação sistemática, básica ou profissional, no Brasil, manifestar-se-iam, em forma crescente, na fase de transição. De feito, à medida que se desintegra a sociedade patriarcal, ampliam-se os mercados e as influências estatais se vão tornando maiores, os contatos indiretos fazem-se mais numerosos e perde relativamente importância a influência formadora dos grupos primários; a educação espontânea não é mais capaz de exercer sua ação integrativa ou homogeneizadora. É mister um sistema deliberado, de âmbito nacional, que, ajustando o indivíduo ao seu meio regional, já por si bem mais amplo do que antiga fazenda latifundiária, o ajuste também ao organismo nacional de que participe, tanto social quanto econômica 
e politicamente. A organização escolar, contudo, mesmo em seu nível primário, nunca pôde corresponder a essa incumbência, nem quantitativa nem qualitativamente.

Basta, para confirmá-lo, um exame dos resultados dos censos de 1920 e 1940, respectivamente, em meados e pràticamente no fim dêste período de consideráveis mutações na vida econômica e social do país. Naquele ano, para uma população em idade escolar primaria, de 4,8 milhões, verificava-

se uma matrícula geral de 1,3 milhões ou seja $27 \%$ e uma freqüência média de 850.000, o que significa e uma frequência média de 850.000 o que significa apenas $18 \%$. Tais dados não só representariam a incapacidade quantitativa do sistema escolar básico, mas depõem claramente contra a qualidade, isto é, o caráter funcional da educação dispensada. Conquanto melhores os resultados de 1940 ainda espelham situação também comprometedora; para uma população necessitada da escola de 5,8 milhões, havia uma matricula geral de 3,3 milhões, ou seja 57\%, e uma frequência média de 2,3 milhões, isto é, $40 \%$. Além disto, o número de aprovações e conclusões de curso é relativamente ainda bem mais reduzido. É evidente que escola básica, complementar, destinada a abranger a população de 10 a 14 anos, compreende número tão restrito de adolescentes que seria pelo menos exagero atribuir ao ensino ministrado nela qualquer função homogeneizadora.

Apreciemos agora o problema do ângulo qualitativo. Ora, em primeiro lugar, como vimos, a economia do país tende assumir, cada vez mais, nesse interregno, embora com intensidade diferente para as várias regiões geoeconômicas, um estilo capitalístico, que pressupõe o desenvolvimento de hábitos, atitudes, preferências e idéias correspondentes. Numa economia monetária, vigoram estímulos que são alheios a uma economia

natural ou pré-capitalista. Sabemos, por exemplo, que o seringueiro da Amazônia (a essa luz mais contemporâneo daquela fase do que desta em que temos que viver), se o preço da borracha duplica, reduz à metade sua produção e, pois, seu trabalho. Não ignoramos também que o contrapeso a essa atitude incôngrua com as premissas subjetivas do capitalismo, se depara no empresário agricultor, industrial ou comerciante, que prefere às grandes receitas líquidas, resultantes de intenso movimento de vendas, os altos lucros unitários. Ninguém desconhece, da mesma sorte, que a distribuição racional dos orçamentos familiares, entre os itens da despensa, segundo a urgência das necessidades, e 
a previsão do futuro e do tempo entre a atividade produtiva e o ócio, não é um comportamento frequente do homem brasileiro, ocorrendo o contrário, de maneira generalizada, em todas as regiões e praticamente em todas as classes. Seria fácil mostrar, igualmente, que o espírito de iniciativa, a disciplina, a diligência, a ordem o "esprit de corps", requeridos numa sociedade que se industrializa, mas dispensáveis numa sociedade patriarcal, baseada no trabalho escravo e em processos de coerção ou compulsão, não foram, no período de transição, inculcados nas gerações submetidas à experiência escolar. Sob êste aspecto, a industrialização pouco se beneficiou da escolari-

dade, fazendo-se mesmo independentemente ou a despeito dela.

Em segundo lugar, o crescimento urbano que corresponde ao desenvolvimento econômico, impõe, por sua vez, estilos de vida que não podiam prescindir da orientação formadora da escola. Nas cidades, o individuo está submetido a uma variedade de influências, não raro antagônicas. Cabe ao ambiente escolar, enquanto seleção inteligente da própria vida, coordenar essa diversidade, transformando o individuo numa personalidade capaz de reagir equilibradamente a essas pressões tumultuárias.

No que toca à educação diferenciada, as considerações já expendidas apontam para o fato de que a educação secundária, ou melhor, o ensino das matérias seriadas ou não, constitutivas do denominado curso secundário, na fase de transição permaneceu, se bem com mais amplitude, uma educação para poucos, selecionados não segundo aptidões, mas de acôrdo com as possibilidades pecuniárias. No Brasil, ainda hoje, a regra é quem não pode, não freqüenta a escola secundária. Mas esta, até 1930, pelo menos, além do caráter distintivo de que revestia seu ensino, preparava para as escolas superiores; não era, pois um fim em si mesma, mas um meio imprescindível de entrada nas faculdades. Quanto ao seu

conteudo, conviria recordar que, consoante José Verisimo, "nada absolutamente distingue a instrução pública brasileira da intrusão pública que se poderia dar em outro país".

O ensino profissional práticamente só existia nas escolas superiores. Já havia, no país desde 1910, um sistema rudimentar de aprendizagem industrial, 
consistente na manutenção do Govêrno de escolas industriais, localizadas nas capitais de vários estados, as quais se destinam a proporcionar cursos mistos de aprendizagem industrial e de caráter cultural. Em 1942, sòmente 6.000 indivíduos estavam recebendo ensino dessa natureza. As escolas superiores constituídas, durante muito tempo, das faculdades de direito, medicina e engenharia, continuaram, mesmo depois da implantação puramente formal da primeira universidade do país, verdadeiras escolas profissionais de grau mais elevado. Embora a contribuição de alguns dêsses institutos tenha sido relevante no domínio da ciência e mesmo da tecnologia, são inegáveis duas de suas falhas: primeiro para atender, conforme as necessidades à procura de profissionais de nível superior do país em crescimento; segundo, no que diz respeito à formação de um genuina cultura nacional, orientada para os problemas materiais, sociais, políticos e econômicos em qualquer de suas manifestações,

não tem sido considerável a participação dessas faculdades; têm elas, sem dúvida, de par com o ensino da ciência e da técnologia estrangeira, transmitindo informações sôbre a cultura dos povos mais adiantados. Corresponde sua falta de orientação pragmática à pobreza de recursos, mas seria sempre de esperar um esfôrço efetivo para superar as precariedades materiais.

O certo é, como já tive oportunidade de afirmar, que a técnologia não corresponde à natureza e magnitude das dificuldades técnicas que se apresentam no caminho do desenvolvimento material. Noutras palavras, a industrialização, no sentido mais amplo, criou oportunidades, mas não teve ainda, na medida razoável, a compensação da pesquiza e da técnica.

Em resumo, a educação sistemática administrada pela organização escolar mal acompanhou o surto do progresso material do país, que não pôde contar com a orientação e a fôrça propulsora de que poderia ter beneficiado.

Agora, porém, entramos em nova fase, na qual não basta o crescimento vegetativo da educação, à proporção que a renda nacional e, conseqüentemente, as receitas públicas avultam. Carecemos, no plano educacional, de deliberado e contínuo esfôrço para estender e melhorar o ensino, articulando-o numa política intencional de

desenvolvimento econômico e de elevação dos níveis culturais. Temos de 
preparar o homem para a nova paisagem física e social emergente no Brasil, que não será apenas o resultado de tendências incoercíveis, a soma dos fatos consumados, mas a resultante de um propósito racional, a consequência de um plano inteligente. Formar os homens de que o Brasil necessita, eis a tarefa da educação. Essa tarefa compreende o estudo e a proposição dos fins, a escolha e o aperfeiçoamento dos métodos e a instituição dos órgãos adequados. Neste tríplice aspecto, salienta-se a função da universidade, que terá de ser não o arquivo do saber acumulado, mas a fonte da cultura, na sua dupla função material e espiritual.

Examinar, em seu conjunto ou isoladamente, o tríplice aspecto do fenômeno educacional, ou seja, a filosofia, a didática e a administração, é encarar a íntima relação entre educação e a economia. A educação é, ao mesmo tempo, um investimento e um consumo; no primeiro sentido, a capacitação dos homens é uma das pedras angulares do desenvolvimento econômico; no segundo, é um dos elementos importantes do bem-estar, indispensável para a fruição plena da vida, e, assim, é o resultado, um fruto do progresso.

Atenta à limitação dos recursos, tão flagrante na economia nacional, impõem-se imperiosa-

mente dois tipos de escolha: o primeiro entre investir ou consumir; e o segundo, entre as múltiplas alternativas de investimentos. Participando de uma natureza ambivalente, a educação está presente em qualquer das escolhas.

No país, na fase de transição e na própria época em que estamos vivendo, as alternativas têm sido selecionadas, intuitivamente, sem a comparação dos diferentes resultados possíveis, sem a previsão dos efeitos totais. Consideravam-se os serviços básicos como êste que nos ocupa, isoladamente, sem a visão do contexto geral de que participa cada um. Desde a metade dos anos 30, provàvelmente em conseqüência dos esforços da mais brilhante plêiade de educadores de que já dispôs a nação, entre os quais se conta o eminente diretor desta Escola, ocorreu gradativo aumento das despesas totais com a educação em relação à renda nacional e ao crescimento da população. Assim, como cumulação dessa campanha, verificou-se, nos últimos dez anos, um aumento de $55 \%$ na frequência média do ensino primário, enquanto que a população em idade escolar cresceu de menos de 30\%, e o produto nacional bruto, em têrmos gerais, pouco mais de $30 \%$.

É evidente que no ponto de vista das necessidades, mesmo apreciadas sómente do ângulo quantititivo, êsses resultados ainda são muito reduzidos. Mas, em primeiro lugar, embora sem 
admitir que seja êsse o esforço ótimo, é mister ter em conta que, nas condições atuais da economia brasileira, é uma utopia, e utopia nefasta, imaginar que todos possam ter a educação básica necessária. Em segundo lugar, as outras alternativas para investimento são também da mais alta hierarquia e, sem lhes atendermos na margem conveniente, menos recursos se poderão desviar no futuro para a educação das massas. Para acelerar, como se supõe, o desenvolvimento econômico, sob as tendências históricas em que se tem processado, é preciso, num plano consistente, nivelar os resultados de cada unidade de capital aplicado. Importa, sobretudo, em qualquer setor, alcançar a mais alta produtividade com os recursos disponíveis. O problema econômico da educação, estritamente considerado, antes de tudo, é o de poder o mais alto rendimento com os recursos que lhe são dedicados.

O princípio de utilização de meios escassos para fins alternativos se apresenta, porém, com a mesma intensidade, em qualquer das duas fases do processo educativo. No ensino básico faz-se, preliminarmente, indispensável uma revisão de sua tábua de valores, de sorte a ajustá-la às necessidades de uma sociedade que se industrializa e deve industrializar-se, que se torna cada vez mais urbana.

$\mathrm{Na}$ hierarquia dos fins, os valores da eficiência devem ganhar uma posição relevante. Isto significa elaborar um currículo em que o imaturo adquira a consciência vital da importância da atividade produtiva, isto é, da criação de utilidades, ou seja, do alcance e dignidade do trabalho em qualquer de suas formas, materiais ou espirituais, e assim, dos hábitos, atitudes e preferências que esse valor implica. Relaciona-se com êsse aspecto o objetivo, por demais ponderável para uma economia subdesenvolvida, de modificar racionalmente, através da transformação do educando, os hábitos de consumo, engendrando um comportamento mais compatível com o processo acumulatório imprescindível.

Em seguida, os métodos de ensino, pôsto se aproveitem da experiência estrangeira, devem adequar-se à carência relativa dos recursos e à cultura brasileira, no seu sentido amplo. Com efeito, a didática brasileira não pode ser a didática norte-americana; esta foi inventada numa economia que tem os mais altos índices de riqueza do mundo, numa palavra, onde as despêsas "per capita" por aluno podem ser pelo menos dez vezes superiores às dêste país. Enquanto os norte-americanos podem dispensar, a cada aluno, atenção maior, tendendo à individualização do ensino, criando as técnicas conseqüentes de 
ma-

nipulação, apropriadas a pequenas classes, no Brasil, ao contrário, temos de esperar da capacidade inventiva de nossos pedagogos, entre, é claro, os limites impostos pelas condições psicológicas e sociais, métodos que permitam tratar grupos mais numerosos de discentes. $O$ que se possa perder, mediante $o$ emprêgo dêsses processos, do ponto de vista individual, é mais do que compensado pelos benefícios que resultam de estender ao maior número o mínimo de educação.

No plano do ensino diferenciado, isto é, preparatório para os vários grupos profissionais, também se aplica o mesmo princípio de economicidade. Em qualquer de seus níveis, importa imprimir-lhe caráter eminentemente utilitário ou pragmático. Isso não significa dispensar o conteúdo pròpriamente cultural dos currículos profissionais, mas que a primeira preocupação deve ser a de formar um profissional competente, apto, mal egresso das escolas, a contribuir com utilidades e serviços à comunidade.

O princípio que impele a buscar o mais alto rendimento por unidade de capital obriga, num país subdesenvolvido e em expansão, que requer cada dia mais especialização, a orientar o ensino vocacional correspondentemente, sem perder de vista que um mínimo de conhecimentos comuns nos setores profissionais é indispensável para

assegurar a flexibilidade conveniente a uma economia em que o mercado de trabalho se caracteriza ainda por grande instabilidade. As técnicas ou especialidades devem, por sua vez, coadunar-se às condições naturais e sociais do país, com o desígnio de prover aos problemas práticos, suscitados pela estrutura de recursos do país e por seu meio social, em transformação, dando lugar à teoria e à técnologia necessárias, pressupostos de uma lídima cultura nacional. Esse esfôrço criador terá de caber, em qualquer parte, a uma minoria e, em qualquer parte, exigirá imaginação, coragem, persistência, dedicação, desprendimento, senso de responsabilidade, capacidade de renúncia às verdades magistrais e às seduções e comodidades do escolasticismo; mas não creio que, em nenhum país, tais virtudes sejam mais reclamadas do que neste. Aqui, com efeito, só um grupo muito reduzido pode alcançar, em face das condições econômicas, as qualificações hábeis. A outorga dêsse benefício a tão poucos, mais aquinhoados pela fortuna ou pela riqueza, corresponde a um custo social, por todos suportado, representando 0 
sacrifício de muitos, e deve-se compensar, comutativamente, pela prestação efetiva de serviços que contribuam para melhorar as condições de vida da coletividade.

* A cópia da brochura original foi obtida junto à Biblioteca da Confederação Nacional da Indústria, então localizada no Rio de Janeiro, em 1996, onde estava registrada sob o número CN00000 983-1 ex.2. Todo o texto foi mantido sob sua grafia original. Junto à margem direita, está indicado o número referente à paginação original.

volta

file://C: Documents and Settings\Administrador\Meus documentos\Minhas Webs\NED... 11/9/2008 


\section{BIOGRAFIA}

\section{Euvaldo Lodi - Biografia** (CPDOC-FGV)}

Euvaldo Lodi nasceu em Ouro Preto (MG), em 1896.

Engenheiro, formou-se pela Escola de Minas e Metalurgia de Ouro Preto, em 1920. Em 1923, passou a integrar a Comissão Nacional de Siderurgia. Ainda durante a década de 20, assumiu a presidência do Centro Industrial de Juiz de Fora (MG). Em 1930, deu apoio ao movimento armado que depôs Washington Luís e levou Getúlio Vargas à presidência da República. Em seguida, filiou-se ao Clube 3 de Outubro, organização política criada com o objetivo de apoiar o aprofundamento das reformas introduzidas pelo novo regime. Ainda nos primeiros anos do governo Vargas, foi designado membro de uma comissão formada pelo Centro Industrial do Brasil (CIB), com o objetivo de sistematizar as opiniões daquela entidade acerca das grandes questões que afetavam o setor industrial.

Membro do conselho diretor da Federação das Indústrias do Rio de Janeiro (FIRJ) entre 1931 e 1936, participou intensamente, nesse período, da montagem de entidades sindicais representativas do patronato industrial. Entre 1933 e 1934, participou dos trabalhos da Assembléia Nacional Constituinte como deputado classista eleito pelo empresariado industrial. Em outubro de 1934, renovou seu mandato de representante classista, participando da legislatura iniciada em maio do ano seguinte. Ainda em 1934, foi nomeado por Vargas membro do Conselho Federal de Comércio Exterior (CFCE). Nos anos que se seguiram, exerceria grande influência nos conselhos técnico-consultivos criados pelo governo federal, principal canal de viabilização das reivindicações dos industriais.

Durante a vigência da ditadura do Estado Novo, assumiu a presidência de 
importantes entidades ligadas ao empresariado industrial, como a CIRJ/FIRJ e a Confederação Nacional da Indústria (CNI). Sua permanência à frente de ambas as entidades se prolongaria até 1954. Como dirigente da CNI, presidiu o Serviço Nacional de Aprendizagem Industrial (SENAI), criado em 1942. Integrou também o Conselho Consultivo da Coordenação de Mobilização Econômica, órgão criado pelo governo federal em virtude do envolvimento do Brasil na Segunda Guerra Mundial e que concentrou grandes poderes durante o período em que existiu. Em 1944, junto com João Daudt de Oliveira, chefiou a delegação brasileira enviada à Conferência de Bretton Woods, nos EUA, que criou o Fundo Monetário Internacional (FMI) e o Banco Internacional para a Reconstrução e o Desenvolvimento (BIRD). Em 1946, foi um dos fundadores do Serviço Social da Indústria (SESI), entidade da qual foi diretor-geral.

Em 1947, elegeu-se deputado federal por Minas Gerais na legenda do Partido Social Democrático (PSD). Reeleito por duas vezes, permaneceu no Câmara Federal até 1956, quando faleceu em um desastre de automóvel entre São Paulo e Jundiaí.

** Documento capturado do site do Centro de Pesquisa e Documentação de História Contemporânea do Brasil da Fundação Getúlio Vargas (CPDOC-FGV). <http://www.cpdoc.fgv.br/nav historia/htm/biografias/ev_bio euvaldolodi.htm>

volta 